\title{
INFLUENCE OF BIOGASS SLURRY AND UREA ON YIELD AND QUALITY OF OKRA(ABELMOSCHUS ESCULENTUS L.) FRUITS
}

\author{
K. Ghimire ${ }^{1}$, D.M. Gautam ${ }^{2}$, K. Mishra ${ }^{3}$, K.R. Pande ${ }^{4}$ and A. G $C^{5}$
}

\section{ABSTRACT}

The study was conducted on sandy loam soil at IAAS Rampur, Chitwan during May to September, 2012 to evaluate the effect of different combinations of biogas slurry and urea on production of okra, laid out in a two-factor RCBD with three replications. Altogether ten treatments consist of two varieties namely Arka Anamika - open pollinated and Jaikisan-62-F1 hybrid and four different levels of biogas slurry and urea combination (urea ${ }_{75 \%}+$ biogas slurry $25 \%$ urea ${ }_{50 \%}+$ biogas slurry s0\% $_{50}$ urea $_{25 \%}+$ biogas slurry $_{75 \%}$ and biogas slurry $\mathrm{1}_{100 \%}$ ) and only inorganic chemical (75:60:50 kg NPK/ha) as control. All treatments were based on fulfillment of required nitrogen for the crop. The results showed that application of urea ${ }_{50 \%}+$ biogas slurry $_{50 \%}$ increased plant height, leaf area, number of leaves and number of nodes at final harvesting. Treatment urea ${ }_{50 \%}+$ biogas slurry $_{50 \%}$ allow maximum number of pickings/plant (23.2) and number of fruits/plant (23.5) resulting highest yield/plant $(376.3 \mathrm{~g})$. Among the varieties, Jaikisan-62 is superior in terms of growth, yield and post harvest character than Arka Anamika. The net return (Rs. 474,136/ha) and mean B/C ratio was highest (2.59) in J aikisan-62 treated with urea ${ }_{50 \%}+$ biogas slurry ${ }_{50 \%}$ So, for the commercial production hybrid variety is suggested.

Key words: Biogas slurry, hybrid variety, open pollinated variety, okra

\section{INTRODUCTION}

Okra (Abelmoschus esculentus L.) is one of the economically important, most popular summer vegetable crops in Terai, inner Terai and lower hills of Nepal (Acharya, 2004). It is a nutritious vegetable, which plays an important role to meet the demand of vegetables of the country during dry season (Adhikari et al., 2009). In 2012, okra was cultivated in 9,609 ha of land with a total production of 108,806 MT and an average productivity of 11.32 MT/ha covering 3.9\% of total vegetable cultivating area in Nepal (MoAD, 2012). However, the productivity is not satisfactory in Nepal (Shakya et al., 2002).

In the context of Nepal where most farmers lack sufficient resources for profitable food production (Adhikari, 2001), dry season vegetables production such as okra through costeffective techniques of fertilization and proper variety selection seems promising. Nitrogen is the most limiting major nutrient in Nepal. Large amount of nitrogen rich biogas slurry is being wasted in the urban and rural Nepal, which can be used as an organic substitute of chemical fertilizers for higher crop production. Different hybrid and open pollinated

\footnotetext{
${ }^{1}$ Plant Protection Officer, District Agriculture Development Office, Parsa

${ }^{2}$ Professor Dr, Institute of Agriculture and Animal Science, Rampur, Chitwan

${ }^{3}$ Associate Professor Dr, Institute of Agriculture and Animal Science, Rampur, Chitwan

${ }^{4}$ Assistant Professor, Institute of Agriculture and Animal Science, Rampur, Chitwan

${ }^{5}$ Agriculture Extension Officer, Ministry of Agricultural Development, Singhdurbar
} 
varieties of okra are grown in Nepal to meet the increasing demand by using excessive inorganic fertilizers but the economic analysis of open pollinated versus hybrid variety has not yet been done.

\section{METHODOLOGY}

The experiment was conducted during April, 2012 to September, 2012 at horticulture farm of IAAS, Rampur, Chitwan having sandy loam textured soil with $4.84 \mathrm{pH}, 2.61 \%$ organic matter, $0.105 \%$ available nitrogen, $96.27 \mathrm{~kg}$ available phosphorus $\mathrm{ha}^{-1}$ and $257.54 \mathrm{~kg}$ available potassium $\mathrm{ha}^{-1}$. The mean maximum temperature $\left(38.3^{\circ} \mathrm{C}\right)$, minimum temperature $\left(25.0^{\circ} \mathrm{C}\right)$, relative humidity $(92.2 \%)$ and rainfall were $(159.7 \mathrm{~mm})$ during the crop growing season. The experiment was laid out in a two factor randomized complete block design with ten treatments; consisting of two variety (Jaikisan-62; hybrid and Arka anamika-open pollinated) and five different levels of urea and biogas slurry combinations (urea ${ }_{75 \%}+$ biogas slurry $25 \%$, urea $_{50 \%}+$ biogas slurry $5_{50 \%}$, urea $25 \%$-biogas slurry $y_{75 \%}$, biogas slurry ${ }_{100 \%}$ and only inorganic chemical as control) and three replications. All treatments were based on fulfillment of required nitrogen for crop. The total experimental area was $235.75 \mathrm{~m}^{2}(20.5 \mathrm{~m} \times 11.5 \mathrm{~m})$ with an individual plot size of $2.5 \mathrm{~m} \times 1.5 \mathrm{~m}$ i.e. $3.75 \mathrm{~m}^{2}$. Seeds soaked overnight in water were sown directly in hills with $50 \mathrm{~cm}$ between rows and $30 \mathrm{~cm}$ within rows, and thinned to one plant per hill 15 DAS. Each plot consisted of 5 rows and each row of 5 plants. Fertilizers were applied at the rate of 75:60:50 Kg NPK/ha. Phosphorous and potash were applied at the time of seed sowing. Urea was applied as per treatment description in which half dose was applied at the time of seed sowing and remaining was top-dressed equally at 30 and 60 days after seed sowing. Biogas slurry was collected in the plastic drum from outlet and tested in laboratory for NPK content. Average nutrient content of biogas slurry collected was $1.78 \%$ total Nitrogen (Kjeldahl digestion), 2.53\% total phosphorous (Bary and Kurtz number one), 1.53\% total potassium (Ammonium acetate extraction method) and $7.17 \mathrm{pH}$. Biogas slurry was applied as per treatment description, $5 \mathrm{~cm}$ away from plant stem for 6 times in 1:1 dilution with water at 15 days interval (i.e. 0, 15, 30, 45, 60 and 75 DAS). Observations on various vegetative, reproductive and quality parameters were recorded. Analysis of variance for all parameters was done using statistical analysis through MSTAT-C program. All the analyzed data were subjected to DMRT for mean separation at $5 \%$ level of significance.

\section{RESULT AND DISCUSSIONS}

\section{PLANT HEIGHT}

There was significantly different among the varieties on plant height at 90 DAS (Table 1). Maximum plant height was observed in Jaikisan-62 $(134.9 \mathrm{~cm})$ than Arka Anamika (129.5 $\mathrm{cm})$. The higher plant height in Jaikisan-62 under the same growing condition might be due to the genetic makeup of the variety and the greater capacity of plants to absorb nutrients from the soil. 
The effect of different combination of biogas slurry manure with urea was highly significant $(\mathrm{P}<0.001)$ (Table 1). At 90 DAS, the highest plant height was recorded in urea ${ }_{50 \%}+$ biogas slurry $y_{50 \%}(138.6 \mathrm{~cm})$ being at par with urea $25 \%$ +biogas slurry ${ }_{75 \%}(136.1 \mathrm{~cm})$ followed by biogas slurry $_{100 \%}(132.8 \mathrm{~cm})$ being at par with urea ${ }_{75 \%}+$ biogas slurry ${ }_{25 \%}(131.3 \mathrm{~cm})$ and lowest in Control $(122.2 \mathrm{~cm})$.

Vijaya and Seethalakshmi (2011) also recorded the continuous increase of plant height in eggplant by supplying $50 \%$ organic and $50 \%$ inorganic manures.

\section{DAYS TO 50\% FLOWERING}

Jaikisan-62 produced 50\% flower earlier (48.1 days) than the Arka Anamika (50.3 days). It might be due to its lowest branching habit of Jaikisan-62 and showed first flower earlier than Arka Anamika which was shown.

Urea ${ }_{50 \%}+$ biogas slurry ${ }_{50 \%}$ produced $50 \%$ flower earlier (48.2 days) being at par with other combinations. However, the chemical fertilizer showed delayed in bearing $50 \%$ flowering (51.5 days). Kafle (2010) also found shorter days to $50 \%$ heading in Green Coronet ( $\left.F_{1}\right)$ cabbage applied with biogas slurry compost than chemical fertilizer.

The earliness in flowering could be attributed to the faster enhancement of vegetative growth and storing sufficient reserved food materials for differentiation of buds into flower buds whereas the delayed flowering by the inorganic fertilizer treatment could be due to extended vegetative phase of the plant by the availability of inorganic nitrogen. These results are in close conformity of the findings of Renuka and Ravi Shankar (1998).

Table 1. Effect of biogas slurry and urea combinations on Plant height, days to 50\% flowering, days to first harvest and harvest duration at Rampur, Chitwan, Nepal, 2012.

\begin{tabular}{|c|c|c|c|c|}
\hline Treatments & $\begin{array}{l}\text { Plant height } \\
90 \text { DAS }(\mathrm{cm})\end{array}$ & $\begin{array}{l}\text { Days to } \\
50 \% \text { flowering }\end{array}$ & $\begin{array}{c}\text { Days to } \\
1^{\text {st }} \\
\text { harvest }\end{array}$ & $\begin{array}{l}\text { Harvest } \\
\text { duration }\end{array}$ \\
\hline \multicolumn{5}{|l|}{ A. $\quad$ Fertilizer level } \\
\hline $\mathrm{N}_{1}$-Control (NPK Chemicals $)$ & $122.22^{c}$ & $51.50^{\mathrm{a}}$ & $55.83^{\mathrm{a}}$ & $44.17^{\mathrm{d}}$ \\
\hline $\mathrm{N}_{2}$ (urea $_{75 \%}+$ biogas slurry $25 \%$ ) & $131.3^{\mathrm{b}}$ & $49.33^{\mathrm{b}}$ & $56.00^{\mathrm{a}}$ & $52.17^{\mathrm{ab}}$ \\
\hline $\mathrm{N}_{3}$ (urea ${ }_{50 \%}+$ biogas slurry $50 \%$ ) & $138.6^{\mathrm{a}}$ & $48.17^{\mathrm{b}}$ & $54.17^{\mathrm{ab}}$ & $54.17^{\mathrm{a}}$ \\
\hline $\mathrm{N}_{4}$ (urea ${ }_{25 \%}+$ biogas slurry ${ }_{75 \%}$ ) & $136.1^{\mathrm{a}}$ & $48.50^{\mathrm{b}}$ & $52.50^{\mathrm{b}}$ & $47.83^{c}$ \\
\hline $\mathrm{N}_{5}$ (biogas slurry $\left.{ }_{100 \%}\right)$ & $132.8^{\mathrm{b}}$ & $48.67^{\mathrm{b}}$ & $53.33^{\mathrm{b}}$ & $51.33^{\mathrm{b}}$ \\
\hline SEM \pm & 1.068 & 0.558 & 0.757 & 0.7904 \\
\hline $\mathrm{LSD}_{0.05}$ & $3.173^{* *}$ & $1.659^{* *}$ & $2.249^{*}$ & $2.348^{* *}$ \\
\hline \multicolumn{5}{|l|}{ B. Varieties } \\
\hline Arka Anamika & $129.46^{b}$ & $50.33^{\mathrm{a}}$ & $55.87^{\mathrm{a}}$ & $49.13^{\mathrm{b}}$ \\
\hline Jaikisan-62 & $134.92^{\mathrm{a}}$ & $48.13^{\mathrm{b}}$ & $52.87^{\mathrm{b}}$ & $50.73^{\mathrm{a}}$ \\
\hline
\end{tabular}




\begin{tabular}{lcccc}
\hline SEM \pm & 0.675 & 0.353 & 0.479 & 0.4999 \\
$\mathrm{LSD}_{0.05}$ & $2.01^{* *}$ & $1.049^{* *}$ & $1.422^{* *}$ & $1.485^{*}$ \\
$\mathrm{CV} \%$ & 3.98 & 2.78 & 3.41 & 5.88 \\
\hline Grand Mean & 132.192 & 49.233 & 54.367 & 49.933
\end{tabular}

Means with same letter within columns do not differ significantly at $p=0.05$ by DMRT, * significant at $5 \%(p \varangle 0.05)$, ** significant at $1 \%(p \varangle 0.01)$

\section{DAYS TO FIRST HARVEST}

Varieties were found highly significant $(P<0.001)$ (Table 1) different for this character. Jaikisan-62 took the shorter period (52.9 days) for days to first harvest than Arka Anamika (55.9 days). It might be due to the earlier flowering occurred in Jaikisan-62.

Similarly, among the fertilizer combinations urea $25 \%+$ biogas slurry $_{75 \%}$ took lowest days to first harvest (52.5 days) being at par with biogas slurry ${ }_{100 \%}$ (53.3 days) and urea ${ }_{50 \%}+$ biogas slurry $_{50 \%}$ (54.2 days). Days to first harvest was found to be comparatively longer in urea ${ }_{75 \%}$ +biogas slurry ${ }_{25 \%}$ (56.0 days) being at par with control (55.8 days).

The variation among the varieties for the first harvest might be due to difference in fruit maturing period. Significant difference among varieties for $50 \%$ flowering also supports the hypothesis. Earliness in okra was highly associated with days from anthesis to edible pod formation (Agrawal et al., 1984). Kafle (2010) also found shorter days to harvest in cabbage in biogas slurry compost treatment and longer days in chemical fertilizer.

\section{HARVEST DURATION}

Duration of the crop harvest varied significantly $(\mathrm{P}<0.05)$ with respect to varieties (Table 1). The higher harvest duration (50.7 days) was recorded in Jaikisan-62 than in Arka Anamika (49.1). Chapagain (2008) also reported similar effect of harvest duration in variety Anokhi (56.7 days) followed by Arka Anamika (54.7 days) and both were statistically at par.

The effect of fertilizer combinations was highly significant $(P<0.001)$ (Table 1$)$ to the harvest duration of crop. Similarly, higher harvest duration was recorded in urea ${ }_{50 \%}+$ biogas slurry $_{50 \%}$ ( 54.2 days) which is statistically at par with urea $75 \%$-biogas slurry $25 \%$ ( 52.2 days) followed by biogas slurry ${ }_{100 \%}$ ( 51.3 days). Lowest harvest days were recorded in control (44.2 days).

Shorter harvest duration in control was due to lack of moisture. Seed took longer time for germination. In the subsequent treatment biogas slurry manure helps to absorb moisture from the soil and kept it for longer time resulting faster germination and crop entered into reproductive phase early due to more suitable environmental condition. According to Duzyaman (1997) harvest duration of okra should be of at least 2 to 3 months for better economic return. 


\section{NUMBER OF FRUITS/PLANT}

The differences between varieties for number of fruits per plant were highly significant $(p<0.01)$, whereas fertilizer level differ significantly $(p<0.05)$ (Table 2$)$. Interaction effect between varieties and applied fertilizer combination was also found significant $(p<0.05)$.

Jaikisan-62 produced highest number of fruits (24.0) per plant than Arka Anamika (20.6). It might be due to the higher plant height of Jaikisan-62 bearing more number of nodes per plant than Arka Anamika and varietal differences may be also the cause.

Similarly, highest number of fruits per plant (23.5) was observed in combinations of urea $_{50 \%}+$ biogas slurry ${ }_{50 \%}$ which is being at par with urea $25 \%$ +biogas slurry ${ }_{75 \%}(22.5)$ and biogas slurry $_{100 \%}$ (22.5) followed by urea ${ }_{75 \%}$ +biogas slurry $25 \%$ (22.1) and the lowest number of fruits per plant were observed in control (21.1). Naidu et al. (1999) observed higher number of fruits per plant (24.3) with application of 50\% FYM + 50\% inorganic nitrogen.

Similar result was obtained by Shahbaz in 2011 where minimum number of fruits per plot (176) in okra was observed in control treatment..

\section{FRTUIT YIELD/PLANT}

The highly significant difference $(p<0.001)$ was observed in the yield per plant of Jaikisan62 and Arka Anamika varieties (Table 2). Jaikisan-62 exhibited higher yield per plant (383.8 g) than the Arka Anamika ( $310.2 \mathrm{~g}$ ). It is because Jaikisan-62 being superior in bearing higher number of fruits per plant and containing higher number of nodes at final harvesting.

The effect of biogas slurry and urea alone or with combinations showed highly significant difference $(p<0.001)$. The highest yield per plant $(376.3 \mathrm{~g})$ was obtained from the urea $_{50 \%}$ +biogas slurry $50 \%$ which was at par with urea $25 \%$ biogas slurry $y_{75 \%}(374.4 \mathrm{~g})$. This is followed by biogas slurry ${ }_{100 \%}$ ( $\left.351.5 \mathrm{~g}\right)$, urea $75 \%$-biogas slurry $_{25 \%}$ (326.7 g) and lowest was observed in control ( $305.9 \mathrm{~g})$. This might be due to bioslurry affected the $\mathrm{pH}$ and organic matter status of the soil which helps to release of indigenous nutrients of soil and soil applied NPK (Shahbaz, 2011). Bokhtiar et al. (2008) reported that organic manures, when applied with chemical fertilizer gave better yield than individual ones.

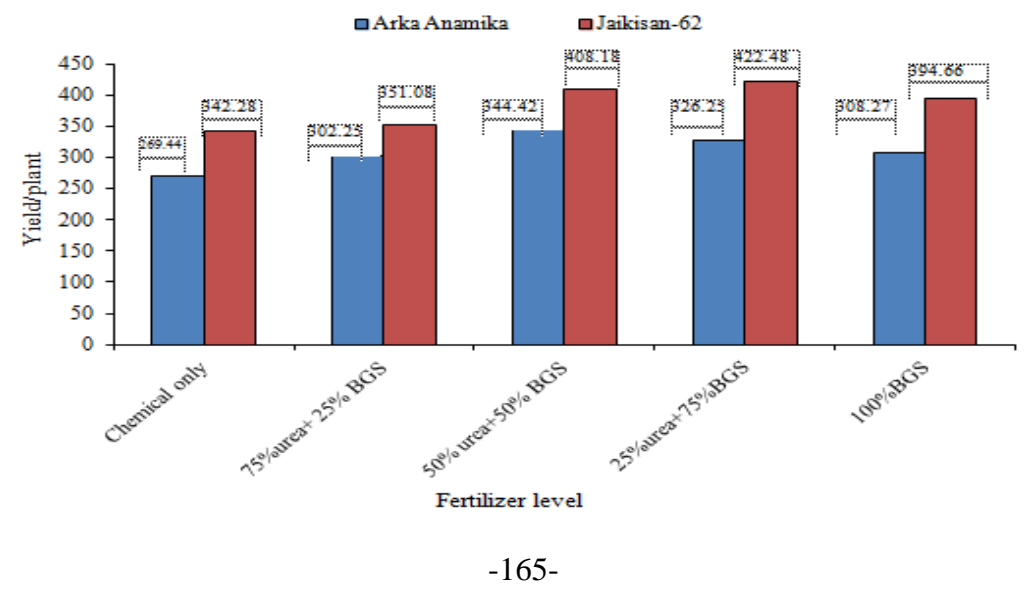


Figure 2. Showing interaction effect of fertilizer level and varieties on yield/plant Ghimire (2011) also found highest yield of sweet pepper in 50\% organic (FYM) and 50\% inorganic (urea) combinations.

The interaction effect of varieties and different combinations of biogas slurry and urea was also found significant $(p<0.05)$. Highest yield per plant $(422.4 \mathrm{~g})$ was obtained by the Jikisan-62 treated with urea $25 \%$ +biogas slurry $75 \%$ which is at par with Jaikisan-62 treated with urea $_{50 \%}+$ biogas slurry ${ }_{50 \%}(408.2 \mathrm{~g})$. Arka Anamika gave highest yield (344.3) with urea $_{75 \%}+$ biogas slurry ${ }_{25 \%}$. But among the interaction treatment lowest yield per plant was obtained by the Arka Anamika treated with chemical (269.4 g).

Nair and Peter (2001) also found that application of both organic and inorganic fertilizers increased fruit yield.

Table 2. Effect of biogas slurry manure and urea combinations on okra varieties on number of fruits/plant and fruit yield/plant at Rampur, Chitwan, Nepal, 2012.

\begin{tabular}{|c|c|c|}
\hline Treatments & Number of fruits/plant & Fruit yield/plant (g) \\
\hline \multicolumn{3}{|l|}{ A. $\quad$ Fertilizer level } \\
\hline $\mathrm{N}_{1}$-Control (NPK $\left.\mathrm{Chemicals}_{\text {Ch }}\right)$ & $21.09^{c}$ & $305.9^{d}$ \\
\hline $\mathrm{N}_{2}$ (urea ${ }_{75 \%}+$ biogas slurry ${ }_{25 \%}$ ) & $22.05^{\mathrm{bc}}$ & $326.7^{c}$ \\
\hline $\mathrm{N}_{3}$ (urea $50 \%+$ biogas slurry $50 \%$ ) & $23.50^{\mathrm{a}}$ & $376.3^{\mathrm{a}}$ \\
\hline $\mathrm{N}_{4}$ (urea $25 \%+$ biogas slurry $75 \%$ ) & $22.46^{\mathrm{ab}}$ & $374.4^{\mathrm{a}}$ \\
\hline $\mathrm{N}_{5}$ (biogas slurry $\left.{ }_{100 \%}\right)$ & $22.46^{\mathrm{ab}}$ & $351.5^{\mathrm{b}}$ \\
\hline SEM \pm & 0.379 & 4.820 \\
\hline $\operatorname{LSD}_{0.05}$ & $1.127^{*}$ & $14.32^{* *}$ \\
\hline \multicolumn{3}{|l|}{ B. Varieties } \\
\hline Arka Anamika & $20.61^{b}$ & $310.2^{b}$ \\
\hline Jaikisan-62 & $24.01^{\mathrm{a}}$ & $383.8^{\mathrm{a}}$ \\
\hline SEM \pm & 0.240 & 3.049 \\
\hline $\mathrm{LSD}_{0.05}$ & $0.713^{* *}$ & $9.058^{* *}$ \\
\hline \multicolumn{3}{|l|}{$A \times B$} \\
\hline SEM \pm & 0.536 & 6.817 \\
\hline $\mathrm{LSD}_{0.05}$ & 1.594 & 20.25 \\
\hline CV\% & 4.17 & 6.40 \\
\hline Grand Mean & 22.312 & 346.951 \\
\hline
\end{tabular}

Means with same letter within columns do not differ significantly at $\mathrm{p}=0.05$ by DMRT, * significant at $5 \%(p \varangle 0.05)$, ** significant at $1 \%(p \varangle 0.01)$ 


\section{EFFCTS ON COSTS OF PRODUCTIOIN, NET RTURN AND BENEFIT COST RATIO}

In Chitwan,the highest total cost of production (NRs. 201,760) was in variety Jaikisan-62 treated with biogas slurry $y_{100 \%}$ and the lowest total cost of production (NRs. 165,740) was found in variety Arka anamika treated with urea $75 \%$-biogas slurry $25 \%$.

Table 3. Benefit cost ratio of okra production by using different level of biogas slurry, urea and their combination at Rampur, Chitwan, Nepal (2012)

\begin{tabular}{|c|c|c|c|c|c|c|}
\hline Treatments & $\begin{array}{l}\text { Total cost of } \\
\text { cultivation } \\
(\mathrm{Rs} / \mathrm{ha})\end{array}$ & $\begin{array}{l}\text { Producti } \\
\text { vity } \\
\text { (t/ha) }\end{array}$ & $\begin{array}{c}\text { Okra selling } \\
\text { price } \\
(\mathrm{Rs} / \mathrm{kg})\end{array}$ & $\begin{array}{l}\text { Gross } \\
\text { Income } \\
\text { (Rs/ha) }\end{array}$ & $\begin{array}{c}\text { Net } \\
\text { benefit } \\
\text { (Rs/ha) }\end{array}$ & $\begin{array}{c}\text { B:C } \\
\text { rati } \\
0\end{array}$ \\
\hline \multicolumn{7}{|l|}{ Manures X variety } \\
\hline $\begin{array}{l}\text { Arka Anamika + } \\
\text { Chemical fertilizer }\end{array}$ & 170655 & 19.52 & 25 & 487917 & 317262 & 1.86 \\
\hline $\begin{array}{l}\text { Jaikisan-62 + } \\
\text { Chemical fertilizer }\end{array}$ & 178955 & 21.40 & 25 & 535083 & 356128 & 1.99 \\
\hline $\begin{array}{l}\text { Arka Anamika + } \\
\text { Urea }_{75 \%}+\text { biogas } \\
\text { slurry }_{25 \%}\end{array}$ & 165740 & 20.22 & 25 & 505417 & 339677 & 2.05 \\
\hline $\begin{array}{l}\text { Jaikisan-62 } \\
+ \text { Urea }_{75 \%}+\text { biogas } \\
\text { slurry }_{25 \%}\end{array}$ & 174040 & 22.70 & 25 & 567500 & 393460 & 2.26 \\
\hline $\begin{array}{l}\text { Arka Anamika + } \\
\text { Urea }_{50 \%}+\text { biogas } \\
\text { slurry }_{50 \%}\end{array}$ & 174980 & 23.19 & 25 & 579667 & 404687 & 2.31 \\
\hline $\begin{array}{l}\text { Jaikisan-62 } \\
+ \text { Urea }_{50 \%}+\text { biogas } \\
\text { slurry }_{50 \%}\end{array}$ & 183280 & 26.30 & 25 & 657417 & 474137 & 2.59 \\
\hline $\begin{array}{l}\text { Arka Anamika } \\
+ \text { Urea }_{25 \%}+\text { biogas } \\
\text { slurry }_{75 \%}\end{array}$ & 184360 & 20.83 & 25 & 520750 & 336390 & 1.82 \\
\hline $\begin{array}{l}\text { Jaikisan-62 } \\
\text { +Urea }_{25 \%}+\text { biogas } \\
\text { slurry }_{75 \%}\end{array}$ & 192660 & 21.95 & 25 & 548833 & 356173 & 1.85 \\
\hline $\begin{array}{l}\text { Arka } \\
\text { Anamika+biogas } \\
\text { slurry }_{100 \%}\end{array}$ & 193460 & 21.58 & 25 & 539417 & 345957 & 1.79 \\
\hline $\begin{array}{l}\text { Jaikisan-62 +biogas } \\
\text { slurry }_{100 \%}\end{array}$ & 201760 & 25.15 & 25 & 628833 & 427073 & 2.12 \\
\hline
\end{tabular}

Biogas slurry was locally available resources, which was obtained at the rate of Rs. 7 per liter. People were ready to pay higher cost if okra is grown organically. The highest net 
return (NRs. 474,136) was obtained from Jaikisan-62 treated with urea ${ }_{50 \%}+$ biogas slurry $50 \%$. The lowest net return (NRs. 317,261) was from control in Arka anamika. B:C ratio was the highest (2.59) from Jaikisan-62 treated with urea ${ }_{50 \%}+$ biogas slurry ${ }_{50 \%}$ and the lowest $\mathrm{B}: \mathrm{C}$ ratio (1.79) ratio was found in Arka anamika treated biogas slurry ${ }_{100 \%}$.

\section{CONCLUSIONS}

Out of the two varieties evauated Jaikisan-62, hybrid was superior to Arka Anamika on growth, reproductive and yield characteristics suggesting that , for the commercial okra cultivation hybrid variety could give better return than open pollinated cultivars. . The benefit cost ratio was highest in Jaikisan-62 in the treatment Urea ${ }_{50 \%}+$ Biogas slurry $_{50 \%}$ combinations and the lowest in Arka Anamika with biogas slurry ${ }_{100 \%}$.

Similarly, between fertilizer combinations the combinations of $50 \%$ organic and $50 \%$ inorganic fertilizer produce higher yield than the control in all cases.

\section{ACKNOWLEDGEMENT}

I would like to express my sincere thanks to the authorities of Institute of Agriculture and Animal Science (IAAS), Rampur, Chitwan, Nepal and also very greatful to the members of my advisory committee.

\section{REFERENCES}

Acharya, U. K. 2004. Effects of plant growth regulators on growth and yield of spring summer season okra under inner Terai condition of Chitwan, Nepal. M.Sc. Thesis submitted to Institute of Agriculture and Animal Sciences, Tribhuwan University, Rampur. 74p.

Adhikari, K.R., S.M. Shakya, A.K. Shukla, K.R. Sharma, Y.-C. Tan and J.-S. Lai. 2009. Efficacy of mulching, irrigation and nitrogen applications on bottle gourd and okra for yield improvement and crop diversification. Irrigation Drainage System 23:25-41

Agrawal, R. C., G. Lal and K. V. Peter. 1984. Biometric analysis of earliness, pod yield, seed yield and their components in okra. Vegetable Science, 11: 85-93.

Bokhtiar, S. M., G. C. Paul and K. M. Alam. 2008. Effects of organic and inorganic fertilizer on growth, yield and juice quality and residual effects on ratoon crops of sugarcane. Journal of Plant Nutrition 31(10):1832-1843.

Chapagain, T.R. 2008. Performance of okra (Abelmoschus esculentus L.) varieties at different sowing dates in spring summer at Rampur, Chitwan, Nepal. M.Sc.Ag. Thesis submitted to Institute of Agriculture and Animal Science, Tribhuwan University. Chitwan Nepal.

Duzyaman, E. 1997. Okra: Botany and Horticulture. In: J. Janick (ed.). Horticultural Reviews, 21: 41 63.

Ghimire, S. 2011. Effect of organic manures and their combination with urea on sweet pepper (Capsicum annum L.) production in mid-hills of Nepal. M.Sc.Ag. Thesis submitted to Institute of Agriculture and Animal Science, Tribhuwan University. Rampur, Chitwan.

$-168-$ 
Kafle, N. 2010. Efficacy of different organic manures management on cabbage (Brassica oleraceae L. var. capitata) at farmer's field of Phulbari, Chitwan. M.Sc.Ag. Thesis submitted to Institute of Agriculture and Animal Science, Tribhuwan University. Chitwan, Nepal.

MoAC. 2011. Statistical information on Nepalese agriculture. Ministry of Agriculture and Co-operative, Agribusiness Promotion and Statistics Division. Singha Durbar, Kathmandu, Nepal. 1p.

Nair, M. and K.V. Peter. 2001. Organic, inorganic fertilizers and their combinations on yield and storage life of hot chillies. Vegetable Science 17:7-10.

Renuka, B. and C. Ravi Shankar. 1998. Effect of organic manures on growth and yield of tomato. South Indian Horticulture 49:216-217.

Shahabz, M. 2011. Potential of bioslurry and compost at different levels of inorganic nitrogen to improve growth and yield of okra (Hibiscus esculetus L.). M.Sc. Thesis submitted to Institute of Soil and Environmental Sciences, University of Agriculture, Faisalabad, Pakistan.

Shakya, S. M., R. C. Bastakoti and D. P. Acharya. 2002. Production system and productivity of selected vegetable crops along the Dumre Besi Sahar road-heads. Technical paper no.5, Forum for Rural Welfare and Agriculture Development, Chitwan Nepal.

Vijaya, K.S and S. Seethalakshmi. 2011. Response of eggplant (Solanum melongena L.) to integrated nutrient management amended soil. International Journal of Scientific \& Engineering Research. 2 ( 8). 5p. 